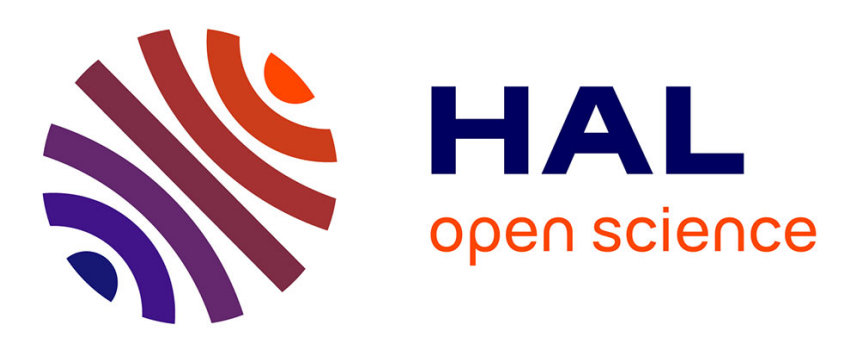

\title{
A relatively reduced Hadean continental crust and implications for the early atmosphere and crustal rheology
}

\author{
Ziaozhi Yang, Fabrice Gaillard, Bruno Scaillet
}

\section{To cite this version:}

Ziaozhi Yang, Fabrice Gaillard, Bruno Scaillet. A relatively reduced Hadean continental crust and implications for the early atmosphere and crustal rheology. Earth and Planetary Science Letters, 2014, 393, pp.210-219. 10.1016/j.epsl.2014.02.056 . insu-01056858

\section{HAL Id: insu-01056858}

\section{https://hal-insu.archives-ouvertes.fr/insu-01056858}

Submitted on 21 Aug 2014

HAL is a multi-disciplinary open access archive for the deposit and dissemination of scientific research documents, whether they are published or not. The documents may come from teaching and research institutions in France or abroad, or from public or private research centers.
L'archive ouverte pluridisciplinaire HAL, est destinée au dépôt et à la diffusion de documents scientifiques de niveau recherche, publiés ou non, émanant des établissements d'enseignement et de recherche français ou étrangers, des laboratoires publics ou privés. 


\section{A relatively reduced Hadean continental crust and implications}

\section{for the early atmosphere and crustal rheology}

Xiaozhi Yang ${ }^{1, *}$, Fabrice Gaillard ${ }^{2}$, Bruno Scaillet $^{2}$

${ }^{1}$ State Key Laboratory for Mineral Deposits Research, School of Earth Sciences and Engineering, Nanjing University, Nanjing 210046, PR China

${ }^{2}$ Institut des Sciences de la Terre d'Orléans, CNRS/Université d'Orléans/BRGM, 1a rue de la Férollerie 45071, Orléans cedex 2, France

*, corresponding author (xzyang@nju.edu.cn)

\section{ABSTRACT:}

It is widely believed that the Earth was strongly reduced during its early accretion, however, the transition from the reduced state that prevailed during Earth's early period to the modern oxidized crust and mantle has never been captured by geochemical surveys on Earth materials as old as $\sim 4.0$ billion years ago. By combining available trace-elements data of igneous zircons of crustal origin, we show that the Hadean continental crust was significantly more reduced than its modern counterpart and experienced progressive oxidation till $\sim 3.6$ billions years ago. We suggest that the increase in the oxidation state of the Hadean continental crust is related to the progressive decline in the intensity of chondritic addition during the late veneer. Inputs of carbon- and hydrogen-rich chondritic materials during the formation of Hadean granitic crust must have favoured strongly reduced magmatism. The conjunction of cold, wet and reduced granitic magmatism during the Hadean implies the production of methane-rich fluids, in addition to the $\mathrm{CO}$ - and $\mathrm{H}_{2}$-rich volcanic species produced by degassing of hot reduced basaltic melts as modified by delivered materials during the late veneer. When the late veneer events ended, magma produced 
by normal decompression melting of the mantle imparted more oxidizing conditions to erupted lavas and the related crust, emitting $\mathrm{CO}_{2}-$ and $\mathrm{H}_{2} \mathrm{O}$-rich gases. Our model suggests that the Hadean continental crust was possibly much weaker than present-day, facilitating intrusion of underplating magma and thus allowing faster crustal growth in the early Earth.

\section{KEYWORDS:}

Oxidation state, zircon, impacts, Hadean continental crust, early atmosphere

\section{Introduction}

Among the physical and chemical parameters used to characterize the Earth, oxidation state, as reflected by its prevailing oxygen fugacity $\left(f \mathrm{O}_{2}\right)$, is a particularly important one. It controls many physicochemical properties and geological processes of the Earth's different reservoirs, and affects the partitioning of elements between coexisting phases and the speciation of degassed volatiles in melts (Collerson and Kamber, 1999; Delano, 2001; McCammon, 2005; Zahnle et al., 2010). In the past decades, numerous studies have been conducted to document the evolution of mantle and atmospheric oxidation states with time in an effort to elucidate possible transitions from an early reduced state to present oxidized conditions. So far, it has been established that the oxidation state of the uppermost mantle is within $\pm 2 \log$ units of the quartz-fayalite-magnetite (QFM) buffer, probably back to $\sim 4.4$ billion years ago $(\mathrm{Ga})$ based on trace-elements studies of mantle-derived komatiites, kimberlites, basalts, volcanics and zircons (Canil, 1997; Delano, 2001; Li and Lee, 2004; Trail et al., 2011). It has been also established that the mantle becomes increasingly reduced with depth, reaching $f \mathrm{O}_{2}$ as low as QFM-4 at $\sim 200 \mathrm{~km}$, 
(McCammon, 2005; Rohrbach et al., 2007). The atmosphere also experienced changes in $f \mathrm{O}_{2}$, being initially low, and rising markedly at $\sim 2.3 \mathrm{Ga}$, during the so-called Great Oxidation Event (GOE) (Collerson and Kamber, 1999; Holland, 2002; Zahnle et al., 2010), progressively reaching its present oxidation state of $\sim 10 \log$ units above QFM (McCammon, 2005). In contrast, the secular evolution of oxidation state of the continental crust, an important boundary layer separating the underlying upper mantle from the atmosphere and buffering the exchanges and interactions between the Earth's interior and exterior, has rarely been addressed, though the presence of evolved crustal materials on the Earth can be traced back to $\sim 4.4 \mathrm{Ga}$ in particular via detrital zircons (e.g. Wilde et al., 2001).

Zircon is a common accessory mineral in nature, occurring in a wide variety of igneous, sedimentary and metamorphic rocks, and is almost ubiquitous in crustal rocks (e.g. Hawkesworth et al., 2010). The physical and chemical durability of zircons makes them widely used in geochemical studies in terms of trace-elements, isotopes, ages and melt/mineral inclusions; in particular, zircons are persistent under most crustal conditions and can survive many secondary processes such as metamorphism, weathering and erosion (Harrison, 2009; Hawkesworth et al., 2010). Thus, zircons in granites of shallow crust may record the chemical/isotopic composition of the deep crust that is otherwise inaccessible, and offer robust records of the magmatic and crust-forming events preserved in the continental crust. In fact, due to the absence of suitable rock records (in particular for periods older than $\sim 4.0 \mathrm{Ga}$ ), studies in recent years concerning the nature, composition, growth and evolution of the continental crust, and especially the Hadean crust, have heavily relied on inherited/detrital zircons (Wilde et al., 2001; Valley et al., 2002; Harrison, 2009; Hawkesworth et al., 2010). Natural igneous zircons incorporate rare-earth elements (REE) and other trace 
elements in their structure at concentrations controlled by temperature, pressure, $\mathrm{fO}_{2}$ and melt composition (Hanchar and van Westrenen, 2007). Petrological observations (e.g. Ballard et al., 2002) and recent experiments (Trail et al., 2011, 2012; Burnham and Berry, 2012) have shown that the concentration of Ce relative to other REE in igneous zircons can be used to constrain the $f \mathrm{O}_{2}$ during their growth. In this report, the change of crustal oxidation state with time is evaluated by using reported trace-elements data for igneous zircons of inferred crustal origin.

\section{Ce-based Zircon oxybarometers}

Available Ce-based zircon oxybarometers include:

$$
\begin{gathered}
\ln \left(\mathrm{Ce} / \mathrm{Ce}^{*}\right)_{C H U R}=(0.1156 \pm 0.0050) \times \ln \left(f O_{2}\right)+\frac{13860 \pm 708}{T}-(6.125 \pm 0.484) \\
\ln \left(\mathrm{Ce} / \mathrm{Ce}^{*}\right)_{C H U R}=(0.0433 \pm 0.008) \times \ln \left(f O_{2}\right)+\frac{7123 \pm 1309}{T}-(3.113 \pm 1.072) \\
\log \left(\mathrm{Ce} / \mathrm{Ce}^{*}\right)_{C H U R}=(0.1625 \pm 0.0143) \times\left(\log \left(f O_{2}\right)-\mathrm{QFM}\right)+(0.274 \pm 0.053)
\end{gathered}
$$

where $\left(\mathrm{Ce} / \mathrm{Ce}^{*}\right)_{C H U R}$ is the chondrite-normalized $\mathrm{Ce}$ anomaly in zircon and $T$ is the zircon crystallization temperature (K). Equations (1) and (2) were obtained with experiments conducted at $10 \mathrm{kbar}$ and $800-1300{ }^{\circ} \mathrm{C}$ on hydrous peraluminous and peralkaline granitic melts, respectively (Trail et al., 2011, 2012), whilst equation (3) is an empirical form (Supplementary Material) derived from experiments conducted at $1300{ }^{\circ} \mathrm{C}$ and 1 bar on a dry andesitic melt (Burnham and Berry, 2012).

Crystallization of zircon requires that its parental melt must be $\mathrm{Zr}$-saturated, and considering the average $\mathrm{Zr}$ concentration in the upper mantle, $\sim 5 \mathrm{ppm}$ (Workman and Hart, 2005), Zr saturation in nature would be mostly, if not only, achieved in felsic, non-peralkaline derivatives (Watson, 1979), agreeing with the general knowledge that natural zircons are almost ubiquitous in crustal materials and the Hadean crustal zircons probably grew from felsic granitic melts (e.g. Harrison, 2009). In this study, 
we have mostly used equation (1), because partial melting of standard crustal protoliths (e.g. Rapp and Watson, 1995; Montel and Vielzeuf, 1997) yields either metaluminous or peraluminous silicic liquids, not peralkaline. The occurrence of strongly peraluminous minerals as inclusions in Hadean crustal zircons, in particular muscovite (e.g. Hopkins et al., 2008), indicates that their original melts were most likely metaluminous or peraluminous (Harrison, 2009). Metaluminous/peraluminous silicic melts reach zircon saturation at reasonable values (<100 ppm), while natural peralkaline melts have very high $\mathrm{Zr}$ solubility (thousands of ppm to several wt\%), which prevents them from crystallizing zircons (Watson, 1979) in the temperature range recorded by most, if not all, crustal zircons, e.g. $650-900{ }^{\circ} \mathrm{C}$ (Fu et al., 2008). In addition, Ce-anomalies in zircons from peralkaline melts are less sensitive to changes in oxygen fugacity and are thus unlikely to yield robust constraints on the oxidation state of natural magmas (Trail et al., 2012). Equation (3) is calibrated on a less felsic (andesitic) metaluminous composition and at high temperature $\left(1300^{\circ} \mathrm{C}\right)$ only: it illustrates that zircon can also record redox conditions in mafic magmas, however, it cannot be applied directly to low-temperature zircons (Antony Burnham, 2013, personal communication).

In addition to the above mentioned Ce-based zircon oxybarometers, there are also a few experimentally calibrated Eu-based zircon oxybarometers (Burnham and Berry, 2012; Trail et al., 2012), which may be equally used to place constraints on the prevailing oxygen fugacity of the environment during the growth of igneous zircons. However, the use of Eu is less straightforward than that of $\mathrm{Ce}$, because, in addition to $f \mathrm{O}_{2}$, the crystallization of feldspar, a major phase for hosting Eu, can also strongly affect the partitioning of Eu into coexisting zircon. Therefore, although experimental studies have demonstrated that the Eu anomaly, Eu/Eu* in igneous zircons is not 
affected by crystallization temperature (Trail et al., 2012), application of Eu-based oxybarometers calibrated from zircon-only (+glass) experiments, is unlikely to be valid in systems crystallizing abundant feldspar such as the continental crust (Supplementary Material).

\section{Data compilation of igneous crustal zircons}

Igneous zircons of crustal origin were compiled from previous reports (Table 1), totalling more than 300 data points (see Supplementary Materials for more details). These zircons, from a range of lithologies, encompass a wide range of formation ages from $\sim 4.4 \mathrm{Ga}$ to almost the present ( $\sim 40 \mathrm{Ma})$. All these zircons were used to study the composition/evolution/growth of the continental crust in previous studies (Hoskin and Ireland, 2000; Ballard et al., 2002; Whitehouse, 2003; Whitehouse and Kamber, 2003;

Cavosie et al., 2006; Bouvier et al., 2012; Mueller and Wooden, 2012).

To ensure the calculation and comparison of $f \mathrm{O}_{2}$ between different periods, the following criteria were applied: (1) the well-studied Hadean Jack Hills and Hadean to Archean Wyoming Province detrital zircons and post-Hadean inherited zircons, typical of continental crust origin, were selected; (2) the contents of REE and other trace elements of the zircons were measured in situ by ion microprobe or laser-ablation inductively-coupled-plasma mass-spectrometry; (3) the selected zircons are of typical igneous origin, as evaluated by their textures and/or by their REE patterns (Fig. 1) and other trace-elements features as summarized by Hoskin and Schaltegger (2003), including depleted light-REE relative to heavy-REE, positive Ce-anomaly, negative Eu-anomaly and reasonable total REE abundance (in rocks of mantle affinity, zircon usually has much lower total REE abundance); (4) for the Hadean detrital zircons, only grains with typical crustal- $\delta^{18} \mathrm{O}$ values, e.g., higher than 
$5.3 \pm 0.3 \%$ for normal mantle (Trail et al., 2011), were chosen (see also Cavosie et al., 2006).

We excluded the following categories of zircons: (1) zircons with abnormal contents/patterns of REE and other trace elements, including data from likely altered zircon grains/domains (e.g. Type 2 zircons of Cavosie et al. (2006), which were excluded because of their too high La contents (e.g. $>0.3 \mathrm{ppm}$ ) relative to igneous crustal zircons $(<0.1-0.2 \mathrm{ppm})$, see Hoskin and Schaltegger (2003)); (2) zircons of the Hadean ages, where grain-/domain-scale age information is not available or whose trace-elements contents and/or O-isotopic compositions are not reliable (e.g., the data in parentheses in Cavosie et al. (2006) who stated that "parentheses around age or $\delta^{18} \mathrm{O}$ data indicate a value that is not considered reliable"), were discarded.

The following assumptions were made: (1) whenever age information and REE and other trace-element abundances were unknown (on the same zircon grains or zones), a general age or a range of age from available reports was assumed (for post-Hadean zircons); (2) the crystallization temperatures of zircons were calculated from the Ti-in-zircon thermometer (Watson et al., 2006) with reported Ti contents, and were assumed $700{ }^{\circ} \mathrm{C}$ for zircons with no reported Ti data. The adoption of $700{ }^{\circ} \mathrm{C}$ in (2) is a reasonable first-order estimate, based on the results of Fu et al. (2008) that the apparent temperatures of $\sim 0.9$ to $4.4 \mathrm{Ga}$ old continental crust zircons are mostly around $700{ }^{\circ} \mathrm{C}$, though some Jack Hills zircons record higher temperatures $>750{ }^{\circ} \mathrm{C}$. These may be caused by Ti contamination introduced along crystal imperfections (Harrison and Schmitt, 2007), or reflect truly higher temperatures of crystallization, as in the case of impact-derived melts (e.g. Darling et al., 2009, see below). It should be further noted that the zircons in Bouvier et al. (2012) from TTGs (2.6-3.0 Ga) and sanukitoids (2.7 Ga), are mostly (>60\%, see Supplementary Material) characterized 
by higher Ti contents (15-33 ppm) and thus higher crystallization temperatures

$\left(>750{ }^{\circ} \mathrm{C}\right)$ - it is not known whether these grains were Ti-contaminated, as argued by Harrison and Schmitt (2007) for some Hadean zircons, and their growth temperatures were overestimated, which would in turn lead to higher calculated $\mathrm{fO}_{2}$, but this does not affect our discussion for the reduced Hadean zircons.

\section{Oxidation state of the continental crust}

The compiled $\left(\mathrm{Ce} / \mathrm{Ce}^{*}\right)_{C H U R}$ and the corresponding $f \mathrm{O}_{2}$ calculated by equation (1) are illustrated in Fig. 2. The chondrite-normalized Ce-anomalies of the Hadean crustal zircons are in general relatively low with a significant proportion (about 30\%) having an $\left(\mathrm{Ce} / \mathrm{Ce}^{*}\right)_{C H U R}<20$ (Fig. 2a), in contrast to the higher values for the post-Hadean grains, which range mostly from 20 to 200 (Fig. 2a). This can be used to argue for a relatively reduced Hadean continental crust. Quantitatively, this is also seen from the calculated $\mathrm{fO}_{2}$ (Fig. 2b) with the Ce-based zircon oxybarometer (equation (1)): the general trend of $f \mathrm{O}_{2}$ in Fig. $2 \mathrm{~b}$ is also apparent with the other two oxybarometers, equations (2) and (3), although the relative uncertainty is much larger for the latter (Supplementary Material). In detail, the $\mathrm{fO}_{2}$ of zircons in modern periods ranges from QFM-2 to QFM+10 (mostly QFM-2 to QFM+6), falling between the present upper mantle and atmosphere (McCammon, 2005), and has not changed significantly since $\sim 3.6 \mathrm{Ga}$. In contrast, the $f \mathrm{O}_{2}$ of zircons prior to $\sim 4.0 \mathrm{Ga}$ shows more reduced values, ranging from QFM-8 to QFM+4 (mostly QFM-6 to QFM+4). From 4.4 to 3.6 Ga, the $f \mathrm{O}_{2}$ recorded by zircons increased progressively, shifting from QFM-6 to QFM-2 for the lower boundaries and from QFM to QFM+6 for the upper boundaries.

An essential question is the uncertainty for the results shown in Fig. 2b. In principle, the uncertainty of the calculated $f \mathrm{O}_{2}$ comes from the uncertainty of the 
measured trace-elements contents, the estimated zircon growth temperature by the Ti-in-zircon thermometer, and the calibration method (equation (1)) itself, and is estimated to be, on average, $\sim 2 \log$ units $(1 \sigma$ : Trail et al., 2011), note that given an error of $50{ }^{\circ} \mathrm{C}$ in temperature for example (see below), the calculated $f \mathrm{O}_{2}$ relative to the QFM system would be shifted by 1.0-1.5 log units; however, the calculated $f \mathrm{O}_{2}$ of the modern continental crust, mostly QFM-2 to QFM+6, are in good agreement with the empirical estimate of the present continental crust (McCammon, 2005), indicating that the uncertainty is probably smaller for most of our data. The wide variation of the recorded $f \mathrm{O}_{2}$ at any given time, up to $\sim 10 \log$ units (Fig. 2b), is essentially comparable to the large compositional variation of trace elements and isotopes reported for these zircons (Hoskin and Ireland, 2000; Ballard et al., 2002; Whitehouse, 2003; Whitehouse and Kamber, 2003; Cavosie et al., 2006; Harrison, 2009; Hawkesworth et al., 2010; Bouvier et al., 2012; Mueller and Wooden, 2012). This may reflect the multiplicity of source materials and processes involved in zircon growth, in particular the likelihood that they may have experienced several melting/crystallization events (actually zircons recovered from the same host material do not necessarily originate from the same rock/melt and crystallize at the same time: e.g. Harrison, 2009; Hawkesworth et al., 2010) and/or that they crystallized at different depths (Supplementary Material). However, the reduced character of the early zircons, and thus the early continental crust, appears to be a feature that makes the Hadean eon to stand unique relative to any other geological periods. This fundamental difference calls for an adequate explanation.

\section{Origin of the reduced Hadean continental crust}

During magmatic differentiation, $\mathrm{Ce} / \mathrm{Ce}^{*}$ of the magma should be fractionated, so 
that the $\mathrm{Ce} / \mathrm{Ce}^{*}$ of the residual liquid cannot always be assumed to be 1 . However, the very large range in $\mathrm{Ce} / \mathrm{Ce}^{*}$, by up to $\sim 2$ orders of magnitude, along with the systematic secular variations seen in the compiled data (Fig. 2a and 2b) strongly suggest that simple fractionation magmatic-processes cannot be the mechanisms leading to the observed data trend. The lower $\mathrm{Ce} / \mathrm{Ce}{ }^{*}$ values of the Hadean zircons, as low as $\sim 3$ to 20 (Fig. 2a), and the implied more reduced Hadean continental crust, possibly as low as QFM-6 (Fig. 2b), can be explained by the following scenarios:

(1) The Hadean continental crust was built from melts of reduced deep-mantle origin, e.g. by deep-seated plume-related events (e.g. Condie, 1998), differing from the modern crust which is produced by differentiation of the oxidized shallow mantle (Fig. 2b). In this scenario, differences between the Hadean and modern crustal zircons would imply that they had sampled Earth's different reservoirs; however, this is not supported by their broadly similar $\varepsilon_{\mathrm{Hf}}$ values (Griffin et al., 2013), REE patterns (Fig. 1a) and total REE contents (Fig. 1b).

(2) The Hadean continental crust was built from materials of the shallow mantle, by processes resembling those operating in modern periods, the only difference being that the Hadean shallow mantle was much more reduced than the modern one. A relatively reduced Hadean shallow mantle could easily explain the observed features of reduced crustal zircons in Fig. 2; however, as explained below, the shallow mantle might have been oxidized very early in Earth's history, e.g. since 4.4 Ga (Trail et al., 2011).

(3) The Hadean continental crust was built from materials, e.g. melts, originating from the already oxidized shallow mantle, as argued by Trail et al. (2011), however, the mantle melts were quite reduced due to modification of materials added during the late veneers. Actually, the lower oxygen fugacity, down to QFM-6 (Fig. 2b), agrees 
well with metal-saturated redox conditions that are imposed by graphite saturation, resulting from the heating of chondritic materials, at low pressure (e.g. Scaillet and Gaillard, 2011; Shirayev and Gaillard, 2014). This is our preferred explanation, which is further elaborated below.

During the Earth's period of late veneers (meteorite bombardments: 4.5-3.8 Ga), a large amount of chondritic material has been transferred to the Earth's surface. Chondrites range from enstatite (E-) types, the most reduced which have nearly all iron as Fe-metal, to the most oxidized carbonaceous ivuna (CI) types, in which all iron occurs as $\mathrm{FeO}$. All these chondrites contain some amounts of $\mathrm{C}$ and $\mathrm{H}$ (from several to tens of wt\%), in the form of carbonaceous materials. These carbonaceous materials when heated and metamorphosed/molten turn into graphite (Hashimoto et al., 2007; Schaefer and Fegley, 2010; Iacono-Marziano et al., 2012a), producing $\mathrm{H}_{2}$-CO-CH${ }_{4}$-rich fluids and imposing very low $f \mathrm{O}_{2}$ to any coexisting magma. The oxidation state at graphite saturation is buffered by the equilibria:

$\mathrm{C}+1 / 2 \mathrm{O}_{2}=\mathrm{CO} \quad$ and $\quad \mathrm{C}+\mathrm{O}_{2}=\mathrm{CO}_{2}$ With decreasing pressure, these equilibria buffer $f \mathrm{O}_{2}$ from QFM-2 at a few thousand bars to QFM-6 at a few bars (Fig. 3), the latter value being comparable to the lowermost $f \mathrm{O}_{2}$ recorded by some of the Hadean crustal zircons in Fig. 2b. Redox buffering by carbon at low pressure has been modelled by Iacono-Marziano et al. (2012b) (see also Huizenga (2005) for the case of graphite-saturated fluids in the C-O-H system). Graphite saturation in silicate melts at shallow crustal levels imposes extremely reduced conditions as shown in Fig. 3 (see also: Shirayev and Gaillard, 2014). Addition of C- and H-rich materials forces magma and coexisting vapour to acquire a strongly reduced oxidation state, e.g., similar to that shown for terrestrial magmas intruding coal-rich sediments as documented for the Siberian Trapps basalts 
(Iacono-Marziano et al., 2012a).

On this basis, we suggest that the reduced $\mathrm{fO}_{2}$ of the Hadean zircons was due to reduced conditions during their growth, caused by the addition of C-bearing materials during the late veneer events. This is actually the only way to explain the relatively lower $f \mathrm{O}_{2}$ given an already oxidized Hadean shallow mantle (QFM \pm 2$)$ by $\sim 4.4 \mathrm{Ga}$ (Trail et al., 2011). Our model is consistent with the recent findings that the abundance of platinum group elements (PGE) was depleted in the early Archean mantle and increased gradually toward the end of Archean, which is interpreted by the progressive mixing-in to the deep mantle of PGE-enriched cosmic material delivered to the Earth by impacts during the period 4.5-3.8 Ga (Maier et al., 2009). Accepting this model, the progressive oxidation of zircons from $\sim 4.4$ to $3.6 \mathrm{Ga}$ reflects the gradual decrease of the intensity of addition of chondritic materials (Fig. 2b), which affected the early Earth (e.g. Martin et al., 2006). At first sight, the increase in $f \mathrm{O}_{2}$ could also be taken as evidence of change in the oxidation state of impactors, which became more oxidized with time (Wood et al., 2006); however, modelling studies have shown that, regardless of the details of calculations and boundary conditions, the main effect of impacts of chondrite-type materials on the growing Earth is the production of reduced magma oceans which coexist with an equally reduced atmosphere (Hashimoto et al., 2007; Schaefer and Fegley, 2010).

We stress that this only means that the oxidation state, and possibly the PGE contents, of the Hadean crust were affected by impacts of chondritic matter (e.g. rich in $\mathrm{C}$ and PGE), but not necessarily that the Hadean crust was built by impacts. The overall granite signature of most Hadean zircons, e.g. apparent low-temperature of crystallization, inclusions of granite minerals and elevated $\delta^{18} \mathrm{O}$, has been taken as evidence for an origin through anatexis of early formed crustal materials (Wilde et al., 
2001; Harrison, 2009; Hawkesworth et al., 2010). Production of silicic derivatives (ie melts with $\mathrm{SiO}_{2}>70 \mathrm{wt} \%$ ) is expected after protracted fractionation only, say after $90 \%$ of a mafic (basalt) or $99 \%$ of an ultramafic magma. For instance, a mantle having 5 ppm $\mathrm{Zr}$, would produce a basalt (10\% melting) with $50 \mathrm{ppm} \mathrm{Zr}$, which then yields (after $90 \%$ crystallization) a rhyolite with $500 \mathrm{ppm} \mathrm{Zr}$, which is about the required value to saturate a silicic melt with zircon (Watson, 1979). This simple example illustrates that, unless mantle/chondritic rocks have much higher $\mathrm{Zr}$ content than documented so far, it is difficult to crystallize high temperature magmatic zircon. Also, it has been shown that, even for zircons grown from impact melt, the crystallization temperature could be much lower than the peak temperature of melting, e.g. by hundreds of degrees (Darling et al., 2009; Wielicki et al., 2012), indicating clearly that zircons produced during impact does not record the peak temperature reached during melting, even if the produced melts were virtually dry. Therefore, the temperature spectra of Hadean crustal zircons, $\sim 600-900{ }^{\circ} \mathrm{C}$ and clustering at $\sim 700{ }^{\circ} \mathrm{C}$ (e.g. Watson and Harrison, 2005; Harrison and Schmitt, 2007; Fu et al., 2008), is not incompatible with our proposed mechanism. We also note that the few terrestrial impacts so far analyzed correspond to isolated and small scale events, whose effect might have been different from that related to the much larger and abundant impacts that typified the early Hadean. In particular, larger impact bolides will have melted the target crust, and even the shallow mantle, to considerably greater depths than the few ones preserved in modern periods, and have affected redox conditions on a much larger scale (e.g. Hashimoto et al., 2007).

\section{Late veneers in the Hadean and redox-buffering}

Late veneers due to extraterrestrial impacts during 4.5-3.8 Ga are thought to have 
played an important role in lunar formation and in resurfacing inner solar system bodies. For the validity of our proposed mechanism in affecting the oxidation state of the Hadean crust, it is necessary to explore whether the late veneers could deliver enough amounts of $\mathrm{C}$ for producing the reduced conditions. Available reports based on some siderophile elements, such as $\mathrm{W}, \mathrm{Pt}$ and $\mathrm{Pd}$, provide some constraints on the possible amount of chondrite materials added to Earth by bombardments, $\sim 0.3-0.7 \%$ of Earth's mass (e.g. Holzheid et al., 2000; Drake and Righter, 2002; Halliday, 2008), and a recent estimate based on stable isotopes of oxygen and other elements comes up with even higher values, $4 \%$ of Earth's mass (Albarède et al., 2013). The physics of impact-related melting is a complex process which depends on a variety of parameters, including the velocity of the impactor, the obliquity of impact angle, the pre-impact temperature of the target, and the size and density of the target (Tonks and Melosh, 1993; Pierazzo et al., 1997; Monteux et al., 2007). As an example, the calculations of Tonks and Melosh (1993: Fig. 16a) show that $\sim 10 \%$ of a planet gets melted, if hit by an impactor at $15 \mathrm{~km} / \mathrm{s}$ and with a mass of $\sim 4 \%$ of the planet. Assuming that the $\mathrm{C}$ brought by the impactor, with an abundance of 3.5\% (e.g. Lodders, 2003), is evenly distributed, then the resulting melt sheet will have a $\mathrm{C}$ content of $\sim 1.4 \mathrm{wt} \%$ (ignoring the $10 \%$ of the impactor vaporized into the atmosphere which will rain out at the surface, see Albarède et al. (2013)). Such a value is higher than the C (as graphite) content needed to reduce the oxygen fugacity of a silicate melt produced by melting of Earth's oxidized mantle materials to about 4-6 log units below QFM-4, which is less than $1 \mathrm{wt} \%$, e.g. from $<0.1$ to $\sim 0.6 \mathrm{wt} \%$ for the saturation of graphite and native iron as a function of decreasing depth (Iacono-Marziano et al., 2012b). Therefore, the conversion of only a minor fraction of the $\mathrm{C}$ in the delivered materials into graphite can cause significant reduction of $\mathrm{fO}_{2}$ in the system (note that, as shown by Schaefer 
and Fegley (2010), graphite is thermodynamically stable in all chondrite materials at the pressure and temperature we are considering here), and it is all the more possible that $\mathrm{C}$ brought by late veneers could produce the reduced conditions recorded by Hadean zircons, in particular for the early Hadean when impacts were heavier and C delivery was probably more profound (Fig. 4).

Accordingly, we propose that (1) the reduced Hadean zircons record largely the fingerprint of late veneers in crustal production, whose redox effects were superior, or superimposed, to those related to internal processes due to normal decompression melting of the mantle, and (2) the Hadean crust records the transition from an early reduced metal-saturated crust-mantle system to the modern oxidized one (Fig. 4). In the absence of significant chondritic inputs during the late Archean, mantle melting via convective upwelling will produce magmas whose oxidation state will broadly mirror that of their source. The oxidation state of the mantle is still debated (e.g. Collerson and Kamber, 1999), but it has been suggested that the mantle may self-oxidize during its growth, by disproportionation of $\mathrm{Fe}^{2+}$ into $\mathrm{Fe}$ and $\mathrm{Fe}^{3+}$ in the deeper mantle (accompanied by Fe loss to the core), a process thought to be essentially operative on Earth-sized, or larger, planets (Frost et al., 2004). The final size of Earth and the core-mantle segregation were achieved within the first 100 millions years after Sun ignition (Kleine, 2011), implying that the mantle oxidation state, if controlled by such a disproportionation mechanism, would have reached oxidizing conditions $(\mathrm{QFM} \pm 2)$ soon after Earth assembly, in any case well before the end of Hadean: in this scenario, the oxidation of the upper mantle may have also been facilitated by a preferential rapid degassing loss of nearly pure hydrogen formed by immiscibility of $\mathrm{H}_{2} \mathrm{O}-\mathrm{H}_{2}$ fluids coexisting with a reduced early mantle (Bali et al., 2013). In this view, the occurrence of some Hadean mantle zircons with $f \mathrm{O}_{2}$ of 
QFM \pm 2 (Trail et al., 2011) then traces back the early existence of oxidized portions of upper mantle, which were not, or less, affected by impact events (Fig. 4). Once the period of intense bombardments was over, mantle melting via adiabatic upwelling produced the bulk of magmas erupted on Earth surface, imparting them the around-QFM value documented by basalts back to $~ 3.6 \mathrm{Ga}$ (Li and Lee, 2004). Our model reconciles the seemingly contradictory $f \mathrm{O}_{2}$ record of zircons, with broadly synchronous reduced and oxidized values in the Hadean. It provides an alternative explanation for the formation of diamond-graphite inclusions in Hadean crustal zircons (given their indigenous origin as argued by Menneken et al. (2007)), which could have been produced by impact events but not necessarily by the appearance of thick continental lithosphere and mature crust-mantle interactions before $\sim 4.2 \mathrm{Ga}$ as speculated by Menneken et al. (2007).

The strong effect of pressure on the redox of graphite-melt equilibria implies that a redox stratification in the Hadean crust could have arisen, from very low $\mathrm{fO}_{2}$ at sub-surface conditions to moderatly reduced conditions at pressures exceeding a few thousand bars (Fig. 3). This may partly explain the vertical variations at a given time in Fig. 2b (reflecting variable pressure of crystallization). However, oxidized zircons may reflect crystallization at depths in the Hadean crust but also crystallization from mantle-derived magmas not affected by impact processes (Trail et al., 2011). We may therefore anticipate a vertical redox stratification with crustal zircons being overall more reduced at shallow depths and mantle zircons recording $f \mathrm{O}_{2}$ similar to that of the modern mantle. At present, the Earth's interior becomes gradually reduced with increasing depth (McCammon, 2005): the deep continental crust is in general more reduced than the overlying shallow crust, and the continental crust as a whole is more oxidized than the underlying mantle (the $f \mathrm{O}_{2}$ of the present deep crust is estimated to 
be similar to or only slightly higher than that of the upper mantle). Our results, based on a dataset in which the predominantly crustal origin of Hadean zircons is apparent, suggest instead that most of the early Hadean crust was very reduced (Fig. 2b), resting on a mantle whose local oxidation state was dictated by the relative intensities of pressure vs. impact $f \mathrm{O}_{2}$-driven mechanisms (Fig. 4), hence leading to a different stratification of $f \mathrm{O}_{2}$ in the Hadean relative to post-Hadean times. The impact events may have caused significant reworking and recycling of the prevailing crust in the Hadean.

\section{Degassing of impact-related melts and implications for early atmosphere}

Regardless of its mode of production, a relatively reduced Hadean continental crust implies a reduced parental magmatism. This has obvious implications for the atmosphere of our planet, which is widely believed to have been affected in one or in another way by magmatic degassing, once the primary atmosphere captured from the solar nebula, if it existed at all, was lost (Zahnle et al., 2010). Globally, impacts may have caused significant melting of the already oxidized upper mantle in the Hadean (Fig. 4). If enough amounts of carbon was delivered, as suggested above (e.g. the addition of $<0.1$ to $\sim 0.6 \mathrm{wt} \% \mathrm{C}$ to a standard basalt with $f \mathrm{O}_{2}$ of QFM triggers graphite and metal Fe crystallization and thus very reduced conditions, see Iacono-Marziano et al. (2012b)), large amounts of reduced basaltic magmas (magma ocean) may have been produced (Hashimoto et al., 2007; Schaefer and Fegley, 2010). If this is correct, reduced portions of shallow mantle may have coexisted with oxidized ones during the Hadean.

Fig. 5 shows the speciation and amount of magmatic volatile species in volcanic gases released from standard basalt as a function of pressure and oxygen fugacity 
calculated using a gas-melt equilibrium model (Gaillard et al., 2011). Also shown is the $f$ parameter developed by Holland (2002) and modified by Kasting et al. (2012) which allows a quantitative evaluation of whether volcanic emanations have an oxidizing $(f<1)$ or reducing $(f>1)$ effect on atmosphere. The main difference between the degassed volatiles under reduced (Hadean) and relatively oxidized (post-Hadean) conditions is that, in the former, reduced species such as $\mathrm{H}_{2} \mathrm{~S}, \mathrm{CO}$ and $\mathrm{H}_{2}$ are more abundant from 1 bar to 1000 bars, while in the latter, oxidized species such as $\mathrm{SO}_{2}$, $\mathrm{CO}_{2}$ and $\mathrm{H}_{2} \mathrm{O}$, are more abundant from 1 bar to 1000 bars (Fig. 5). Clearly, the impact-related reduced mantle magma could have injected appreciable amounts of reduced gases into the atmosphere in the early Hadean, and the atmosphere prior to $\sim 4.0$ Ga was probably strongly reduced, as indicated by the $f$ parameters much higher than 1 (at either 1 bar or 100 bars: Fig. 5). Overall, Fig.5 shows that the volcanic gases required for the transition from a reduced to an oxidized atmosphere were already in place at $\sim 3.6 \mathrm{Ga}$. The process that delayed this transition to $\sim 2.3 \mathrm{Ga}$ (Fig. $2 \mathrm{~b}$ ) may be due to modifications in the ratio of subaerial-submarine volcanism triggered by the geodynamics of the late Archean (Gaillard et al., 2011).

Fig. 6 shows the speciation of C-O-H-bearing gases coexisting with silicic melts saturated in graphite at various temperatures and pressures. A putative Hadean hot (i.e. $1100{ }^{\circ} \mathrm{C}$ ) graphite-saturated silicic melt will have its $f \mathrm{O}_{2}$ buffered in the range QFM-7 to QFM-3 at pressures up to $~ 1000$ bars. The corresponding gases are dominated by $\mathrm{CO}$ and $\mathrm{H}_{2}$ (Fig. 6b), as for basalt magmas (Fig. 5). For the possible conditions of cold silicic magmas recorded by Hadean zircons, e.g., $<900{ }^{\circ} \mathrm{C}$ and by average $\sim 700{ }^{\circ} \mathrm{C}$ (Watson and Harrison, 2005), the range of redox conditions is mostly QFM-6 to QFM-2, in good agreement with the zircon $\mathrm{fO}_{2}$ imprint (Fig. 2b), and the coexisting gases are dominated by $\mathrm{CH}_{4}$ and $\mathrm{H}_{2} \mathrm{O}$ (Fig. 6b). A likely lower limit for zircon 
crystallization temperature is given by the solidus of granite magmas which varies with pressure and gas composition. For instance, at 1000 bars, the solidus of haplogranite with an $\mathrm{XH}_{2} \mathrm{O}$, the molar fraction of $\mathrm{H}_{2} \mathrm{O}$ in the mixed gases, of 0.35 is $\sim 840{ }^{\circ} \mathrm{C}$ (Ebadi and Johannes, 1991), decreasing to $\sim 800{ }^{\circ} \mathrm{C}$ at 2000 bars (Figure 3). If provision is made for the role of components such as Fe or F, which will depress solidus temperatures by up to $50{ }^{\circ} \mathrm{C}$ (Scaillet and MacDonald, 2001), and for uncertainties associated with Ti-in-zircon-based temperatures (e.g. Watson et al., 2006; Fu et al., 2008), the two sets of temperatures overlap reasonably well with each other. The parental magma of the Hadean crust thus released reduced gases to the Hadean atmosphere, the balance between different reduced species $\left(\mathrm{H}_{2}, \mathrm{CO}\right.$ and $\left.\mathrm{CH}_{4}\right)$ being dictated by the local silicic vs. mafic relative contributions (Fig. 4). On a global scale, however, during the impact dominated regime of Earth's early evolution, reduced “mafic-sourced" species ( $\mathrm{CO}$ and $\left.\mathrm{H}_{2}\right)$ probably dominated, interspersed with small ponds of colder, silicic-sourced, gases, whose $\mathrm{CH}_{4}-\mathrm{H}_{2} \mathrm{O}$-rich composition (and $\mathrm{H}_{2} \mathrm{~S}$ ) may have favored the emergence of prebiotic organic compounds (Parker et al., 2011) and influenced climate on the early Earth (Kasting, 2005). If hydrous, cold and felsic magmas were significantly involved in the formation of the Hadean crust, this conjunction constitutes a formidable recipe to inject in the atmosphere volatiles composed of $\mathrm{H}_{2} \mathrm{O}$ and $\mathrm{CH}_{4}$. On the contrary, planets like Mars have a crust constituted of hot basaltic magmas, releasing $\mathrm{CO}-\mathrm{H}_{2}$ mixtures into their atmosphere in which $\mathrm{CH}_{4}$ is thermodynamically unstable (Gaillard et al., 2013). The production of $\mathrm{CH}_{4}$-bearing fluids may actually be a unique feature of planets having a felsic crust formed during a late veneer event.

\section{Implications for crustal processes and rheology in the Hadean}


The presence of liquid water on Earth's surface can be tracked back to $\sim 4.4 \mathrm{Ga}$ (Wilde et al., 2001; Valley et al., 2002), and it is widely accepted that water has played a critical role in the formation and evolution of the continental crust (Campbell and Taylor, 1983; Whitney, 1988; Kleinhanns et al., 2003). Feldspars are the dominant minerals in the Earth's crust, and control many chemical and physical properties, hence geological processes affecting the crust and even the whole continental tectonics (Bürgmann and Dresen, 2008). Recent experimental studies have shown that the solubility of water as H-related point defects in feldspar is strongly $f \mathrm{O}_{2}$-dependent, although in a highly non-linear fashion (Yang, 2012). The overall pattern displays an inverted bell-shaped curve: solubility is very high under reduced conditions, e.g., below QFM-4, decreasing sharply as $f \mathrm{O}_{2}$ increases down to a pronounced minimum at $\mathrm{QFM} \pm 2$ and then increasing as $f \mathrm{O}_{2}$ increases up to $\mathrm{QFM}+6$, although the dependence of water solubility on temperature or pressure is relatively simple, being enhanced at elevated temperature or pressure at otherwise identical conditions (Yang, 2012).

Water solubility in nominally anhydrous minerals is defined as the equilibrium water content of a mineral coexisting with a hydrous fluid or melt (Keppler and Bolfan-Casanova, 2006). Accepting the involvement of hydrous and cold magmas in building the Hadean continental crust as discussed above and elsewhere (Watson and Harrison, 2005; Harrison, 2009), feldspars in the reduced crust prior to $\sim 4.0 \mathrm{Ga}$ had probably very high $\mathrm{H}$ contents, e.g., saturated concentration values may have been acquired. The progressive oxidation of the crust from $\sim 4.4$ to $3.6 \mathrm{Ga}$ (especially from $\sim 4.0$ to 3.6 Ga: Fig. 2 b), with $f \mathrm{O}_{2}$ from as low as $\sim$ QFM-6 prior to $\sim 4.0 \mathrm{Ga}$ to as low as $\sim$ QFM-2 at $\sim 3.6 \mathrm{Ga}$, implies in turn that feldspars of the continental crust progressively lost their dissolved H-species. Such a release in H-bearing fluids can markedly lower the melting point of rock systems and thus promote melting, so that 
the continental crust in this period may have also undergone continuous partial melting. Hence, the Hadean continental crust was probably more prone to dehydration, melting and ensuing crystallization, e.g. the so-called intra-crustal differentiation which is important for crustal growth (Rudnick, 1995; Hawkesworth et al., 2010). Overall, the presence of dehydration-related hydrous fluids and/or partial melts would markedly lower the rheological strength and enhance deformation of the continental crust (Tullis and Yund, 1980), so that dynamical processes such as crustal folding, flowing, uplifting, reworking and even subduction-related recycling may have been affected: for example, low viscosity of the deep continental crust would make it favorable for underplating and/or intruding of magma, through which new crustal materials are injected leading to crustal growth (Meissner and Mooney, 1998). Altogether, this suggests that, prior to $\sim 3.6 \mathrm{Ga}$, the continental crust was very likely characterized by higher rates of crustal construction (growth and differentiation). This may provide a mechanism for explaining the higher growth rates of the continental crust prior to $\sim 3.0 \mathrm{Ga}$ as suggested in almost all available crust growth models (e.g. Harrison, 2009; Hawkesworth et al., 2010).

\section{Acknowledgements}

We thank Kent Condie, Dustin Trail, Catherine McCammon, Antony Burnham, Ilya N Bindeman and J. Michael Palin for open, inspiring and friendly discussions. Editorial handling by Bernard Marty and constructive comments by Cin-Ty Lee and four anonymous reviewers helped to improve the manuscript. This study was supported by

the the Natural Science Foundation of China (41372041), the National Basic Research Program of China (973 project: 2014CB845904), the Recruitment Program of Global Young Experts, and the European Research Council (ERC grant number 279790). 


\section{References}

Albarède, F., Ballhaus, C., Blichert-Toft, J., Lee, C.T., Marty, B., Moynier, F., Yin, Q.Z., 2013. Asteroidal impacts and the origin of terrestrial and lunar volatiles. Icarus 222, 44-52.

Bürgmann, R., Dresen, G., 2008. Rheology of the lower crust and upper mantle: evidence from rock mechanics, geodesy, and field observations. Annu. Rev. Earth Planet. Sci. 36, 531-567.

Bali, E., Audetat, A., Keppler, H., 2013. Water and hydrogen are immiscible in Earth's mantle. Nature 495, 220-223.

Ballard, J.R., Palin, J.M., Campbell, I.H., 2002. Relative oxidation states of magmas inferred from $\mathrm{Ce}(\mathrm{IV}) / \mathrm{Ce}(\mathrm{III})$ in zircon: application to porphyry copper deposits of northern Chile. Contrib. Mineral. Petrol. 144, 347-364.

Bouvier, A.S., Ushikubo, T., Kita, N.T., Cavosie, A.J., Kozdon, R., Valley, J.W., 2012. Li isotopes and trace elements as a petrogenetic tracer in zircon: insights from Archean TTGs and sanukitoids. Contrib. Mineral. Petrol. 163, 745-768.

Burnham, A.D., Berry, A.J., 2012. An experimental study of trace element partitioning between zircon and melt as a function of oxygen fugacity. Geochim. Cosmochim. Acta 95, 196-212.

Campbell, I.H., Taylor, S.R., 1983. No water, no granites - No oceans, no continents. Geophys. Res. Lett. 10, 1061-1064.

Canil, D., 1997. Vanadium partitioning and the oxidation state of Archaean komatiite magmas. Nature $389,842-845$.

Cavosie, A.J., Valley, J.W., Wilde, S.A., E.I.M.F., 2006. Correlated microanalysis of zircon: trace element, $\delta^{18} \mathrm{O}$, and $\mathrm{U}-\mathrm{Th}-\mathrm{Pb}$ isotopic constraints on the igneous origin of complex $>3900 \mathrm{Ma}$ detrital grains. Geochim. Cosmochim. Acta 70, 5601-5616.

Collerson, K.D., Kamber, B.S., 1999. Evolution of the continents and the atmosphere inferred from Th-U-Nb systematics of the depleted mantle. Science 283, 1519-1522.

Condie, K.C., 1998. Episodic continental growth and supercontinents: a mantle avalanche connection? Earth Planet. Sci. Lett. 163, 97-108.

Darling, J., Storey, C., Hawkesworth, C., 2009. Impact melt sheet zircons and their implications for the Hadean crust. Geology 37, 927-930.

Delano, J.W., 2001. Redox history of the Earth's interior since 3900 Ma: implications for prebiotic molecules. Orig. Life Evol. Bios. 31, 311-341.

Drake, M., Righter, K., 2002. Determining the composition of the Earth. Nature 416, 39-44.

Ebadi, A., Johannes, W., 1991. Beginning of melting and composition of first melts in the system Qz-Ab-Or- $\mathrm{H}_{2} \mathrm{O}-\mathrm{CO}_{2}$. Contrib. Mineral. Petrol. 106, 286-295.

Frost, D.J., Liebske, C., Langenhorst, F., McCammon, C.A., Tronnes, R.G., Rubie, D.C., 2004. Experimental evidence for the existence of iron-rich metal in the Earth's lower mantle. Nature 428, 409-412.

Fu, B., Page, F.Z., Cavosie, A.J., Fournelle, J., Kita, N.T., Lackey, J.S., Wilde, S.A., Valley, J.W., 2008. Ti-in-zircon thermometry: applications and limitations. Contrib. Mineral. Petrol. 156, 197-215.

Gaillard, F., Scaillet, B., Arndt, N.T., 2011. Atmospheric oxygenation caused by a change in volcanic degassing pressure. Nature 478, 229-232.

Gaillard, F., Michalski, J., Berger, G., McLennan, S., Scaillet, B., 2013. Geochemical reservoirs and timing of sulfur cycling on Mars. Space Sci. Rev. 174, 251-300.

Griffin, W.L., Belousova, E.A., O'Neill, C., O'Reilly, S.Y., Malkovets, V., Pearson, N.J., Spetsius, S., Wilde, S.A., 2013. The world turns over: Hadean-Archean crust-mantle evolution. Lithos http://dx.doi.org/10.1016/j.lithos.2013.08.018.

Halliday, A.N., 2008. A yound Moon-forming giant impact at 70-110 million years accompanied by late-stage mixing, core formation and degassing of the Earth. Phil. Trans. Royal. Soc. 366, 4163-4181.

Hanchar, J.M., van Westrenen, W., 2007. Rare earth element behavior in zircon-melt systems. Elements 3, 37-42.

Harrison, T.M., Schmitt, A.K., 2007. High sensitivity mapping of Ti distributions in Hadean zircons. Earth Planet. Sci. Lett. 262, 9-19.

Harrison, T.M., 2009. The Hadean crust: evidence from >4 Ga zircons. Annu. Rev. Earth Planet. Sci. 37, 479-505.

Hashimoto, G.L., Abe, Y., Sugita, S., 2007. The chemical composition of the early terrestrial atmosphere: formation of a reducing atmosphere from CI-like material. J. Geophys. Res. 112, 
E05010, doi: 05010.01029/02006JE002844.

Hawkesworth, C.J., Dhuime, B., Pietranik, A.B., Cawood, P.A., Kemp, A.I.S., Storey, C.D., 2010. The generation and evolution of the continental crust. J. Geol. Soc. (London) 167, 229-248.

Holland, H.D., 2002. Volcanic gases, black smokers, and the Great Oxidation Event. Geochim. Cosmochim. Acta 66, 3811-3826.

Holzheid, A., Sylvester, P.J., O'Neill, H.S., Rubie, D.C.P., H., 2000. Evidence for a late chondritic veneer in the Earth's mantle from high-pressure partitioning of palladium and platinum. Nature 406, 396-399.

Hopkins, M., Harrison, T.M., Manning, C.E., 2008. Low heat flow inferred from >4 Gyr zircons suggests Hadean plate boundary interactions. Nature 456, 493-496.

Hoskin, P.W.O., Ireland, T.R., 2000. Rare earth element chemistry of zircon and its use as a provenance indicator. Geology 28, 627-630.

Hoskin, P.W.O., Schaltegger, U., 2003. The composition of zircon and igneous and metamorphic petrogenesis. Rev. Mineral. Geochem. 53, 27-62.

Huizenga, J.M., 2005. COH, an excel spreadsheet for composition calculations in the C-O-H system. Comput. Geosci. (U. K.) 31, 797-800.

Iacono-Marziano, G., Marecal, V., Pirre, M., Gaillard, F., Arteta, J., Scaillet, B., Arndt, N.T., 2012a. Gas emissions due to magma-sediment interactions during flood magmatism at the Siberian Traps: gas dispersion and environmental consequences. Earth Planet. Sci. Lett. 357-358, 308-318.

Iacono-Marziano, G., Gaillard, F., Scaillet, B., Polozov, A.G., Marecal, V., Pirre, M., Arndt, N.T., 2012b. Extremely reducing conditions reached during basaltic intrusion in organic matter-bearing sediments. Earth Planet. Sci. Lett. 357-358, 319-326.

Kasting, J.F., 2005. Methane and climate during the Precambrian era. Precambrian Res. 137, 119-129.

Kasting, J.F., Catling, D.C., Zahnle, K., 2012. Atmospheric oxygenation and volcanism. Nature 487, E1.

Keppler, H., Bolfan-Casanova, N., 2006. Thermodynamics of water solubility and partitioning. In: Keppler, H., Smyth, J.R. (Eds.) Water in Nominally Anhydrous Minerals, Mineralogical Society of America, Washington D C, pp. 193-230.

Kleine, T., 2011. Earth's patchy late veneer. Nature 477, 168-169.

Kleinhanns, I.C., Kramers, J.D., Kamber, B.S., 2003. Importance of water for Archaean granitoid petrology: a comparative study of TTG and potassic granitoids from Barberton Mountain Land, South Africa. Contrib. Mineral. Petrol. 145, 377-389.

$\mathrm{Li}$, Z.X.A., Lee, C.T., 2004. The constancy of upper mantle $\mathrm{fO}_{2}$ through time inferred from V/Sc ratios in basalts. Earth Planet. Sci. Lett. 228, 483-493.

Lodders, K., 2003. Solar system abundance and condensation temperature of the elements. Astrophys. J. 591, 1220-1247.

Maier, W.D., Barnes, S.J., Campbell, I.H., Fiorentini, M.L., Peltonen, P., Barnes, S., Smithies, R.H., 2009. Progressive mixing of meteoritic veneer into the early Earth's deep mantle. Nature 460, 620-623.

Martin, H., Albarède, F., Claeys, P., Gargaud, M., Marty, B., Morbidelli, A., Pinti, D.L., 2006. Building of a habitable planet. Earth, Moon, Planets 98, 97-151.

McCammon, C., 2005. The paradox of mantle redox. Science 308, 807-808.

Meissner, R., Mooney, W., 1998. Weakness of the lower continental crust: a condition for delamination, uplift, and escape. Tectonophysics 296, 47-60.

Menneken, M., Nemchin, A.A., Geisler, T., Pidgeon, R.T., Wilde, S.A., 2007. Hadean diamonds in zircon from Jack Hills, Western Australia. Nature 448, 917-920.

Montel, J.M., Vielzeuf, D., 1997. Partial melting of metagreywackes, 2: compositions of minerals and melts. Contrib. Mineral. Petrol. 128, 176-196.

Monteux, J., Coltice, N., Dubuffet, F., Richard, Y., 2007. Thermo-mechanical adjustement after impacts during planetary growth. Geophys. Res. Lett. 34, doi:10.1029/2007GL031635.

Mueller, P.A., Wooden, J.L., 2012. Trace element and Lu-Hf systematics in Hadean-Archean detrital zircons: implications for crustal evolution. J. Geol. 120, 16-30.

Parker, E.T., Cleaves, H.J., Dworkin, J.P., Glavin, D.P., Callahan, M., Aubrey, A., Lazcano, A., Bada, J.L., 2011. Primordial synthesis of amines and amino acides in a 1958 Miller $\mathrm{H}_{2} \mathrm{~S}$-rich spark discharge experiments. Proc. Natl. Acad. Sci., doi: 10.1073/pnas.1019191108.

Pierazzo, E., Vickery, A.M., Melosh, H.J., 1997. A reevaluation of impact melt production. Icarus 127, 408-423.

Rapp, R.P., Watson, E.B., 1995. Dehydration melting of metabasalt at 8-32 kbar: implications for continental growth and crust-mantle recycling. J. Petrol. 36, 891-931.

Rohrbach, A., Ballhaus, C., Golla-Schindler, U., Ulmer, P., Kamenetsky, V.S., Kuzmin, D.V., 2007. 
Metal saturation in the upper mantle. Nature 449, 456-458.

Rudnick, R.L., 1995. Making continental crust. Nature 378, 571-578.

Scaillet, B., MacDonald, R., 2001. Phase relations of peralkaline silicic magmas and petrogenetic implications. J. Petrol. 42, 825-845.

Scaillet, B., Gaillard, F., 2011. Redox state of early magmas. Nature 480, 48-49.

Schaefer, L., Fegley, B., 2010. Chemistry of atmospheres formed during accretion of the Earth and other terrestrial planets. Icarus 208, 438-448.

Shirayev, A.A., Gaillard, F., 2014. Local redox buffering by carbon at low pressures and the formation of moissanite -- natural SiC. Eur. J. Mineral. 125, doi: dx.doi.org/10.1127/0935-1221/2013/0025-2339.

Tonks, W.B., Melosh, H.J., 1993. Magma ocean formation due to giant impacts. J. Geophys. Res. 98, 5319-5333.

Trail, D., Watson, E.B., Tailby, N.D., 2011. The oxidation state of Hadean magmas and implications for early Earth's atmosphere. Nature 480, 79-82.

Trail, D., Watson, E.B., Tailby, N.D., 2012. Ce and Eu anomalies in zircon as proxies for the oxidation state of magmas. Geochim. Cosmochim. Acta 97, 70-87.

Tullis, J., Yund, R.A., 1980. Hydrolytic weakening of experimentally deformed Westerly granite and Hale albite rock. J. Struct. Geol. 2, 439-451.

Valley, J.W., Peck, W.H., King, E.M., Wilde, S.A., 2002. A cool early Earth. Geology 30, 351-354.

Watson, E.B., 1979. Zircon saturation in felsic liquids: experimental results and applications to trace element geochemistry. Contrib. Mineral. Petrol. 70, 407-419.

Watson, E.B., Harrison, T.M., 2005. Zircon thermometer reveals minimum melting conditions on earliest Earth. Science 308, 841-844.

Watson, E.B., Wark, D.A., Thomas, J.B., 2006. Crystallization thermometers for zircon and rutile. Contrib. Mineral. Petrol. 151, 413-433.

Whitehouse, M.J., 2003. Rare earth elements in zircon: a review of applications and case studies from the outer Hebridean Lewisian Complex, NW Scotland. Geol. Soc. Spec. Publ. 220, 49-64.

Whitehouse, M.J., Kamber, B.S., 2003. A rare earth element study of complex zircons from early Archaean Amîtsoq gneisses, Godthåbsfjord, south-west Greenland. Precambrian Res. 126, 363-377.

Whitney, J.A., 1988. The origin of granite: the role and source of water in the evolution of granitic magmas. Geol. Soc. Am. Bull. 100, 1886-1897.

Wielicki, M.M., Harrison, T.M., Schmitt, A.K., 2012. Geochemical signatures and magmatic stability of terrestrial impact produced zircon. Earth Planet. Sci. Lett. 321-322, 20-31.

Wilde, S.A., Valley, J.W., Peck, W.H., Graham, C.M., 2001. Evidence from detrital zircons for the existence of continental crust and oceans on the Earth 4.4 Gyr ago. Nature 409, 175-178.

Wood, B.J., Walter, M.J., Wade, J., 2006. Accretion of the Earth and segregation of its core. Nature 441, 825-833.

Workman, R.K., Hart, S.R., 2005. Major and trace element composition of the depleted MORB mantle (DMM). Earth Planet. Sci. Lett. 231, 53-72.

Yang, X., 2012. An experimental study of $\mathrm{H}$ solubility in feldspars: effect of composition, oxygen fugacity, temperature and pressure and implications for crustal processes. Geochim. Cosmochim. Acta 97, 46-57.

Zahnle, K., Schaefer, L., Fegley, B., 2010. Earth's earliest atmosphere. Cold Spring Harb. Perspect. Biol. 2, a004895. 


\section{Figure Captions}

2 Fig. 1 (a) chondrite-normalized REE patterns, and (b) Ce-anomaly vs. total REE

3 content of the Hadean and post-Hadean igneous crustal zircons compiled in Table 1.

4 The REE patterns are in general similar for all the zircons (a), and 5 data-points with

5 significant deviation (4 with total REE contents of 4000-5000 or 1 with Ce-anomaly

6 of $~ 900)$ are not shown in (b).

7

8 Fig. 2 (a) chondrite-normalized Ce-anomalies of the compiled zircons, and (b)

9 oxidation state of the continental crust calibrated by the Ce-based oxybarometer

10 (equation (1)). Horizontal lines in (a) are only for reference, and inset in (b) shows the

11 available models about the declined intensity of bombardments during late veneers

12 from $~ 4.4$ to 3.5 Ga modified after Martin et al. (2006). Circles and squares denote

13 Hadean and post-Hadean zircons, respectively, and grey triangles in (b) are zircons of

14 mantle origin (from Cavosie et al. (2006) who reported $>15$ grains with

15 normal-mantle-like $\delta^{18} \mathrm{O}$, however, many of these grains are either without reported

16 ages or their ages $/ \delta^{18} \mathrm{O}$ are regarded not reliable by Cavosie et al., see text and also

17 Trail et al. (2011)). Dotted area illustrates the shallow mantle oxidation state (to $\sim 4.4$

$18 \mathrm{Ga})$.

Fig. 3 Plot of $f \mathrm{O}_{2}$ at graphite saturation buffered by the equilibria: $\mathrm{C}+1 / 2 \mathrm{O}_{2}=\mathrm{CO}$ and $\mathrm{C}+\mathrm{O}_{2}=\mathrm{CO}_{2}$. We assume here a $\mathrm{C}-\mathrm{O}$ system, but the figure would not be altered if considering a C-O-H system or a C-O-H-S system (Iacono-Marziano et al., 2012a).

23 Calculations are carried out at $1200{ }^{\circ} \mathrm{C}$ but changing temperature has a moderate 24 effect on this equilibria that is primarly pressure-driven. Inset is the squared region on 25 a different scale. 
Fig. 4 Sketch illustrating the relationships between bombardments, crustal oxidation state, mantle convection and degassed volatiles since $\sim 4.4 \mathrm{Ga}$ (not to scale). In detail, we show changes in impact intensity, degassed volatiles and continental crust redox, and the overall effects on the composition of the atmosphere. Oxidation state of the upper mantle is assumed unchanged since $\sim 4.4 \mathrm{Ga}(\mathrm{QFM} \pm 2)$, and impact-related melts were in general reduced (likely coexisting with metallic blobs) (Hashimoto et al., 2007; Schaefer and Fegley, 2010). The top panel shows that, during a stage of heavy bombardments (early Hadean), the intense impacts induced large volumes of reduced melts, which gave rise to reduced continental crust and reduced gases such as $\mathrm{H}_{2}, \mathrm{H}_{2} \mathrm{~S}, \mathrm{CO}$ and $\mathrm{CH}_{4}$. Once created, reduced portions of continental crust may have protected the underlying regional oxidized upper mantle from being reduced by impacts, and the atmosphere at this stage was probably reduced. The middle panel shows that, during a stage of moderate bombardments (middle Hadean), oxidized continental crust may be formed directly from the oxidized upper mantle together with oxidized volatiles such as $\mathrm{H}_{2} \mathrm{O}, \mathrm{CO}_{2}$ and $\mathrm{SO}_{2}$ which could have been released into the atmosphere. The lower panel shows that, at the end of bombardments (late Hadean), the continental crust was mostly oxidized, due to differentiation of oxidized upper mantle, and the degassed gases were dominated by oxidized species so that the atmosphere was probably vented by oxidized volcanic species at this stage. The small blue tear drops are used to illustrate metal saturation, which were settling either in local impact-melts pools or beyond the Fe disproportionation line (Frost et al., 2004).

Fig. 5 Calculated volatile species and content in volcanic gases as a function of $\mathrm{fO}_{2}$ and pressure. We considered a basaltic magma containing $\mathrm{H}_{2} \mathrm{O}=0.34 \%, \mathrm{CO}_{2}=0.34 \%$, 
and $\mathrm{S}=0.15 \%$ (broadly a standard tholeiite). (a) degassed volatiles at reduced conditions (buffered by iron-wüstite, IW, حQFM-4), (b) degassed volatiles at relatively oxidized conditions (QFM-0.5), and (c) the $f$ parameter developed by Holland (2002) and modified by Kasting et al. (2012) and the ratio of $\mathrm{SO}_{2} /\left(\mathrm{H}_{2} \mathrm{~S}+\mathrm{S}_{2}+\mathrm{SO}_{2}\right)$ in the model of Gaillard et al. (2011). Solid lines, 1 bar; dashed lines, 100 bar. All calculations are performed at $1300{ }^{\circ} \mathrm{C}$.

Fig. 6 (a) temperature- $f \mathrm{O}_{2}$ patterns of a silicic melt saturated in graphite calculated at various pressures, for a bulk volatile content of $\mathrm{H}_{2} \mathrm{O}=3 \mathrm{wt} \%$ and $\mathrm{C}=2 \mathrm{wt} \%$. The progressive decrease in $\mathrm{fO}_{2}$ with decreasing pressure reflects the progressive oxidation of graphite (hence reduction of coexisting melt) into $\mathrm{CO}_{2}$ and $\mathrm{CO}$ as magma degasses during uprise (approximately $1 \mathrm{wt} \%$ of graphite reacts out between 1000 bars and 1 bar). (b) calculated volatile species in gases coexisting with the silicic melt shown in (a) as a function of temperature and pressure. Note the preponderance of $\mathrm{H}_{2} \mathrm{O}$ and $\mathrm{CH}_{4}$ gas species in the low temperature range at either 100 or 1000 bars, while $\mathrm{CO}$ and $\mathrm{H}_{2}$ dominate at high temperatures. Vertical lines in (b) show the solidus of the haplogranite system at the corresponding pressure and appropriate $\mathrm{XH}_{2} \mathrm{O}$ (Ebadi and Johannes, 1991). The same lines are shown in (a), solidus lines converging to the 1 bar haplogranite eutectic $\left(960^{\circ} \mathrm{C}\right)$. 
70 Table 1 Characteristics of zircons for data compilation

\begin{tabular}{llll}
\hline Locality & Host material & Age (Ma) & Reference \\
\hline Boggy Plain pluton, Australia & Aplite & 417 & Hoskin and Ireland (2000) \\
Boggy Plain pluton, Australia & Diorite & 417 & Hoskin and Ireland (2000) \\
Mawson Coast, Antarctica & Charnockite & $954-985$ & Hoskin and Ireland (2000) \\
Syros, Greece & Gabbroic ophiolite & 80 & Hoskin and Ireland (2000) \\
Manilla, Australia & Plagiogranite & $1000-1200$ & Hoskin and Ireland (2000) \\
Sri Lanka & Gravel & 570 & Hoskin and Ireland (2000) \\
Statjord Formation, North Sea & Sandstone & $2650-3100$ & Hoskin and Ireland (2000) \\
New South Wales, Australia & Gabbro & $420-430$ & Hoskin and Ireland (2000) \\
ChuquicamataEl Abra, Chile & Igneous intrusions & $\sim 40$ & Ballard et al. (2002) \\
Godthåbsfjord, south-west Greenland & Gneiss & 3650 & Whitehouse (2003) \\
Howmore, South Uist & Granite & 1702 & Whitehouse (2003) \\
Superior Province, Canada & TTG ${ }^{\dagger}$ \& Sanukitoid $\quad 2600-3000 ~ \& ~ 2700$ & Bouvier et al. (2012) \\
Godthåbsfjord, south-west Greenland & Gneiss & 3850 & Whitehouse and Kamber (2003) \\
Jack Hills, Australia & Detrital zircons (Hadean) & Cavosie et al. (2006) \\
Jack Hills, Australia & Detrital zircons (Hadean) & Bouvier et al. (2012) \\
northern Wyoming Province & Detrital zircons (Hadean-Archean) & Mueller and Wooden (2012) \\
\hline
\end{tabular}

$71 \dagger$ : TTG, tonalite-trondhjemite-granodiorite.

72 : Ma, million years ago. Hadean and Hadean-Archean detrital zircons were in-situ measured on the same zones or grains for U-Pb ages and

73 trace-elements composition.

74 *: for Hadean crustal zircons, only those with typical crustal- $\delta^{18} \mathrm{O}$ values, e.g., higher than 5.3 $\pm 0.3 \%$ or for normal mantle (Trail et al., 2011 ), were

75 chosen (see also text). 

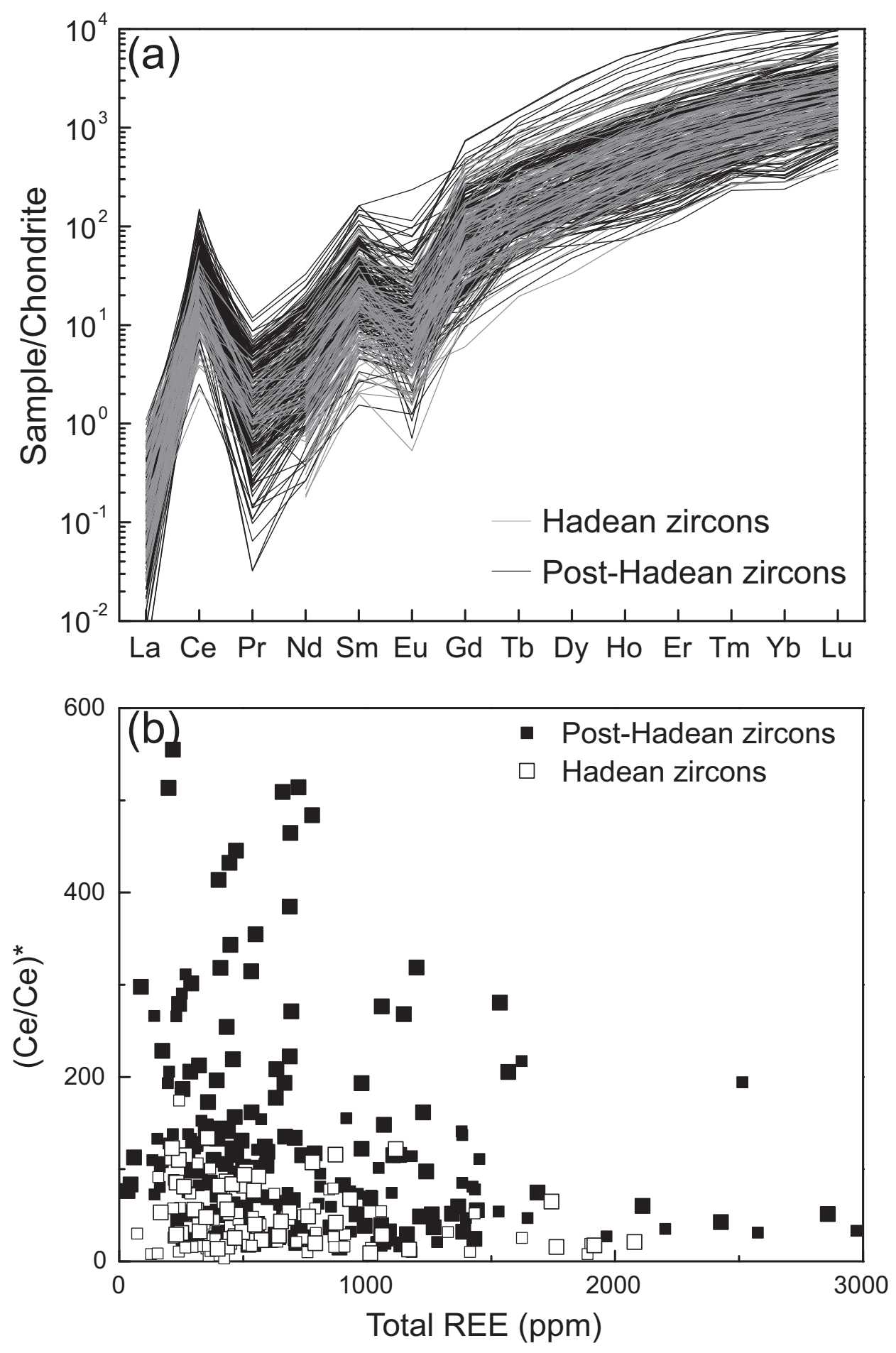

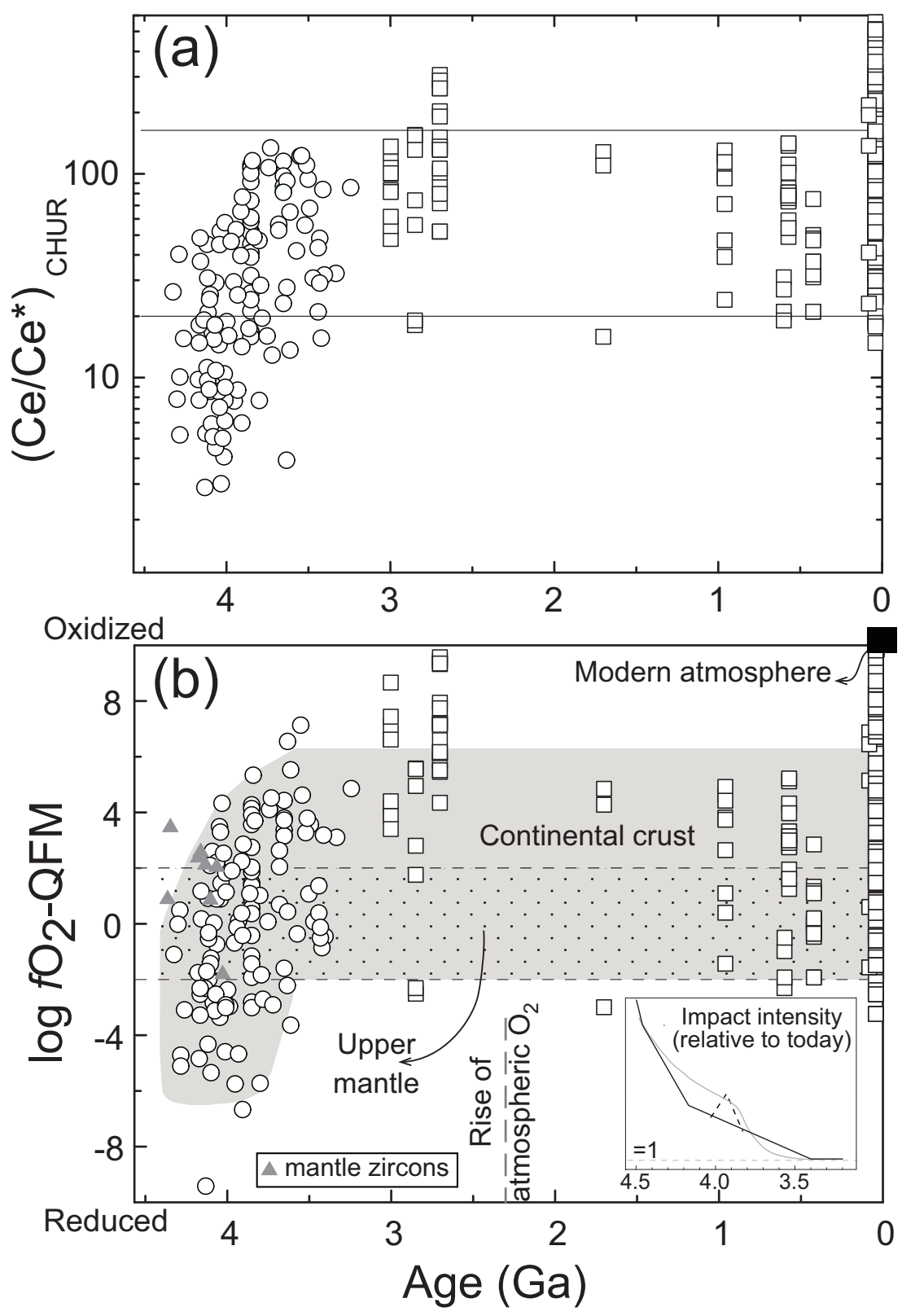


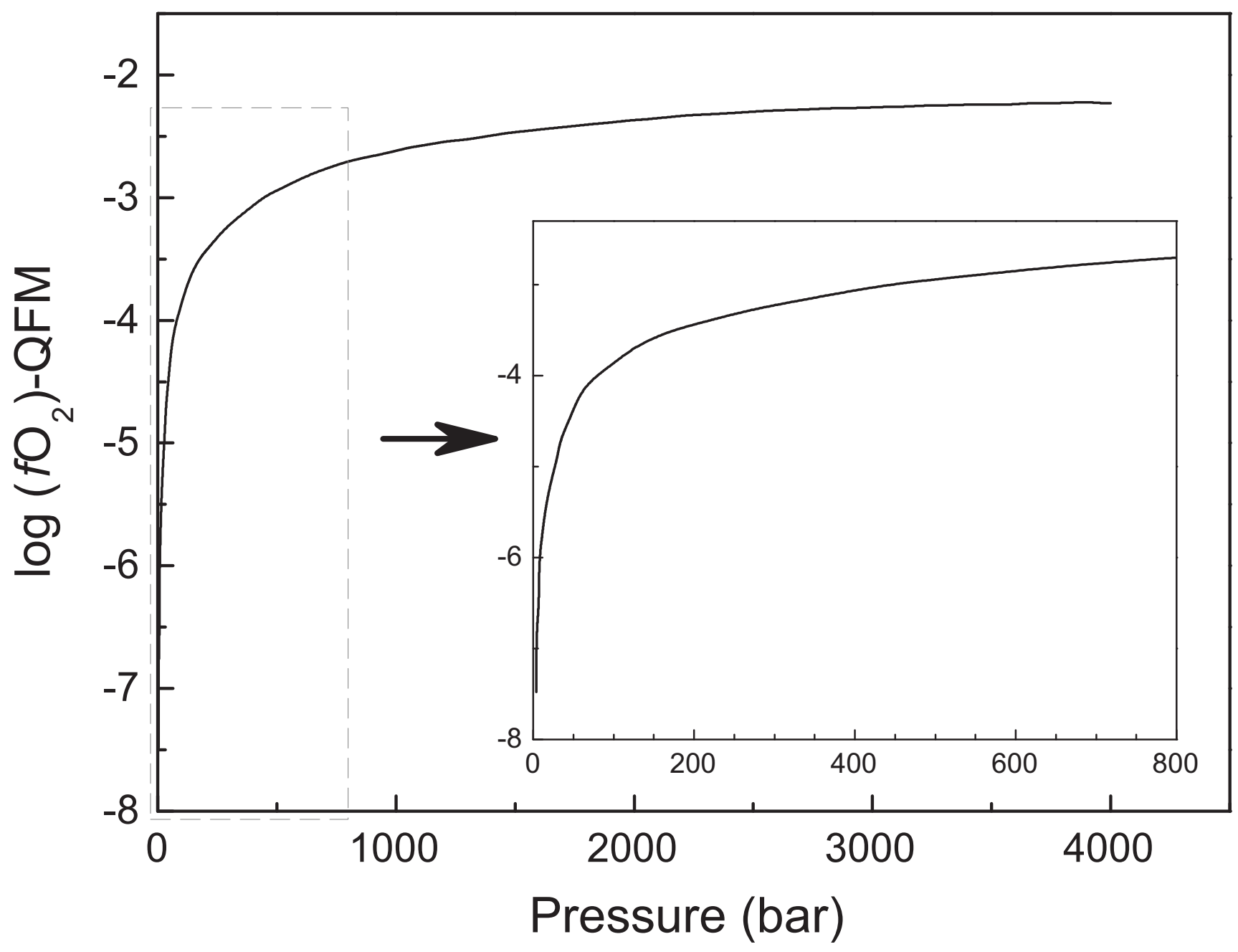



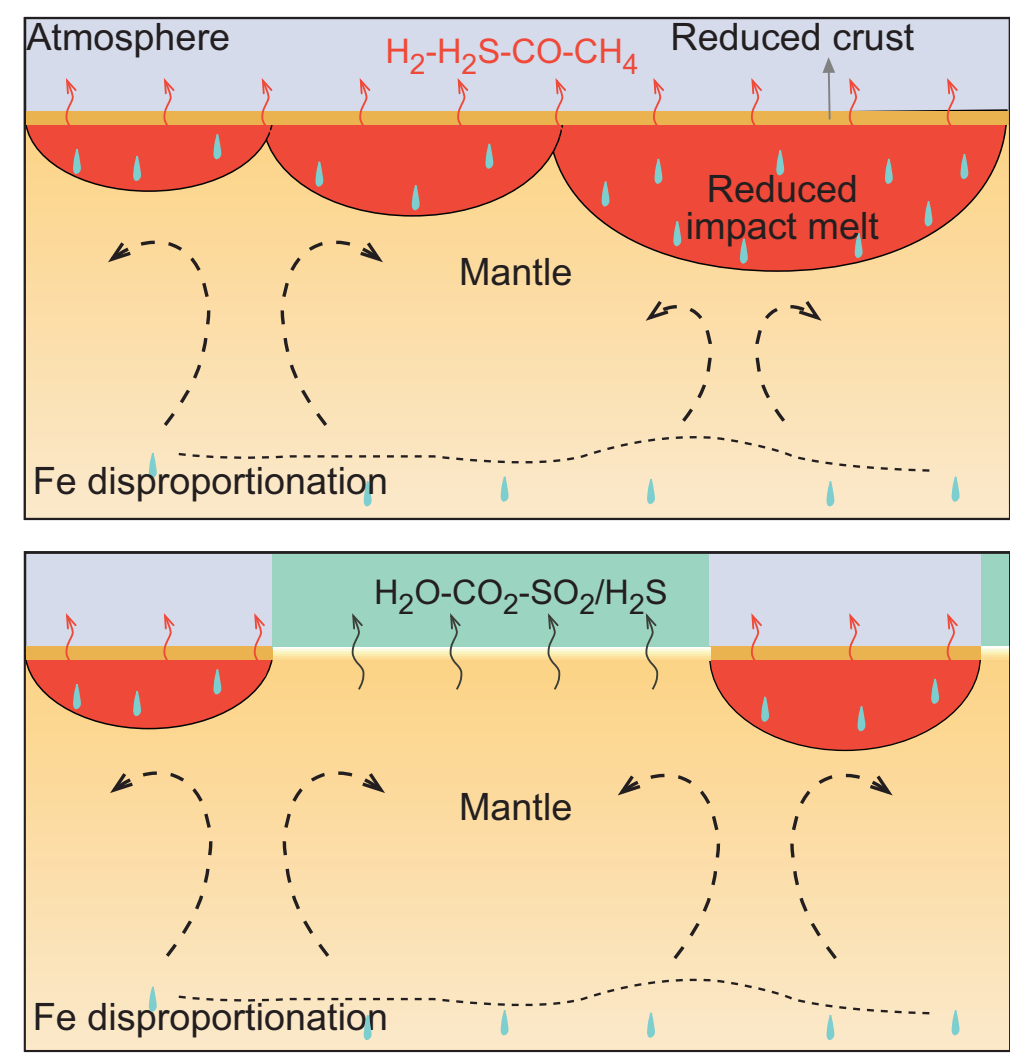

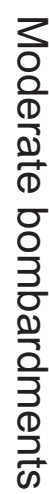

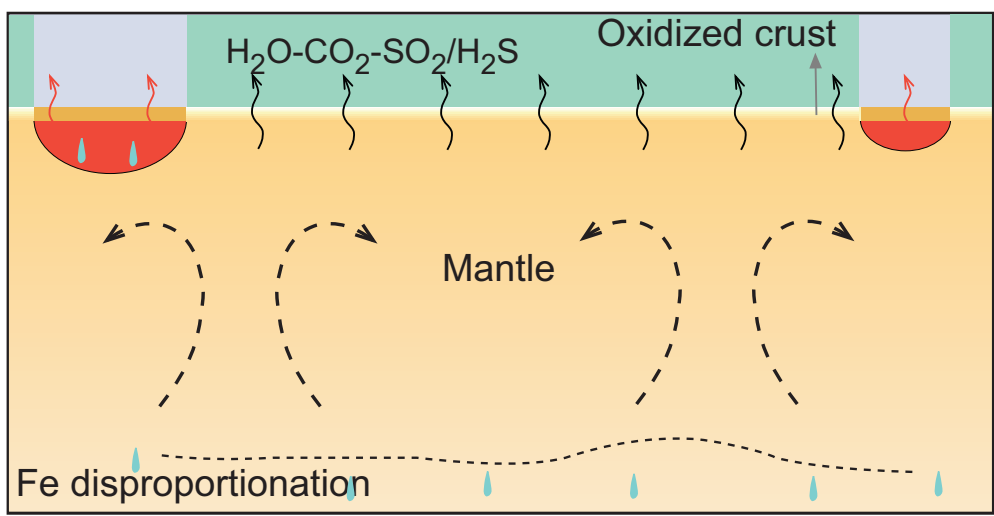

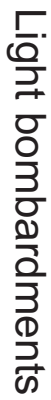




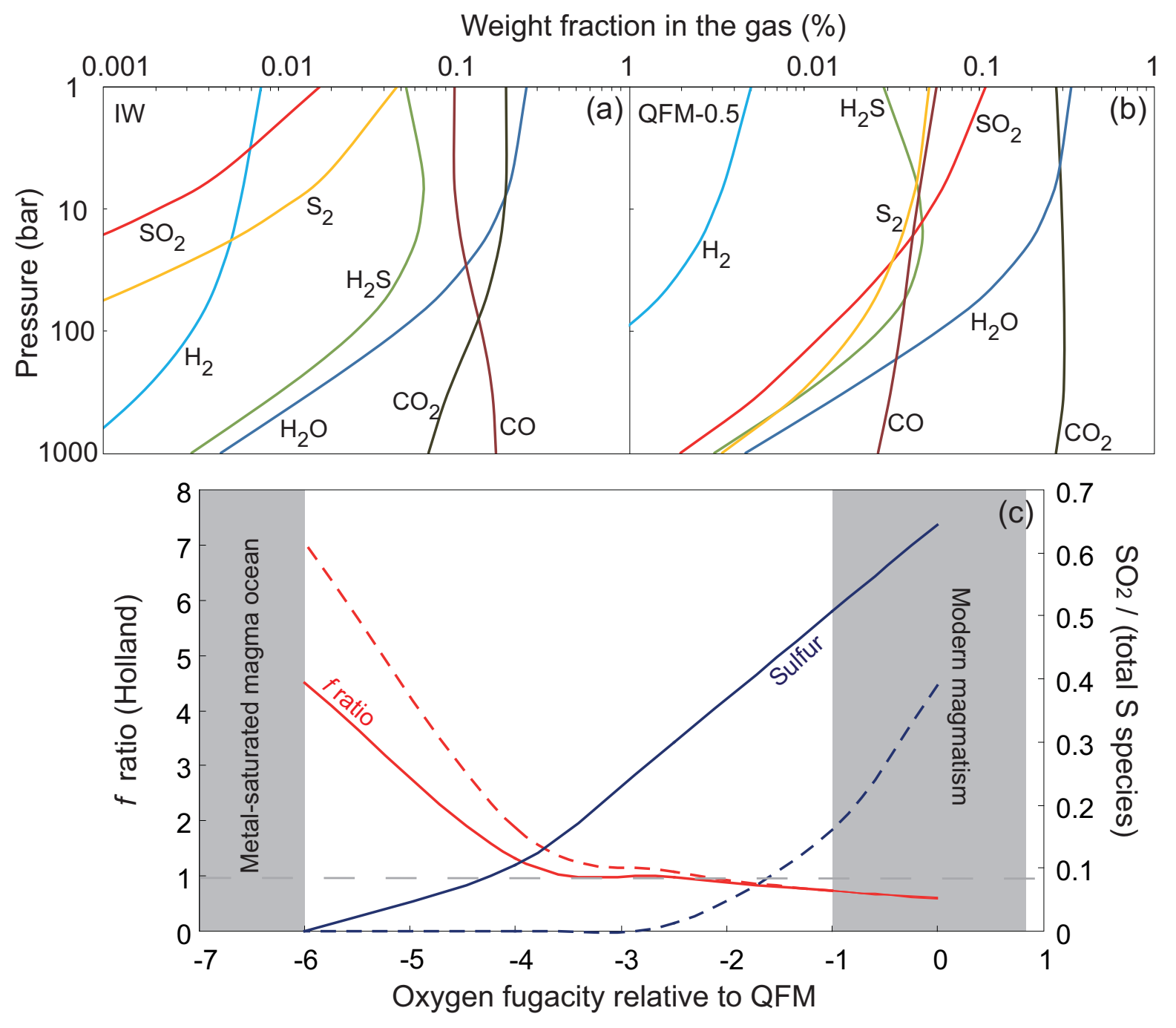



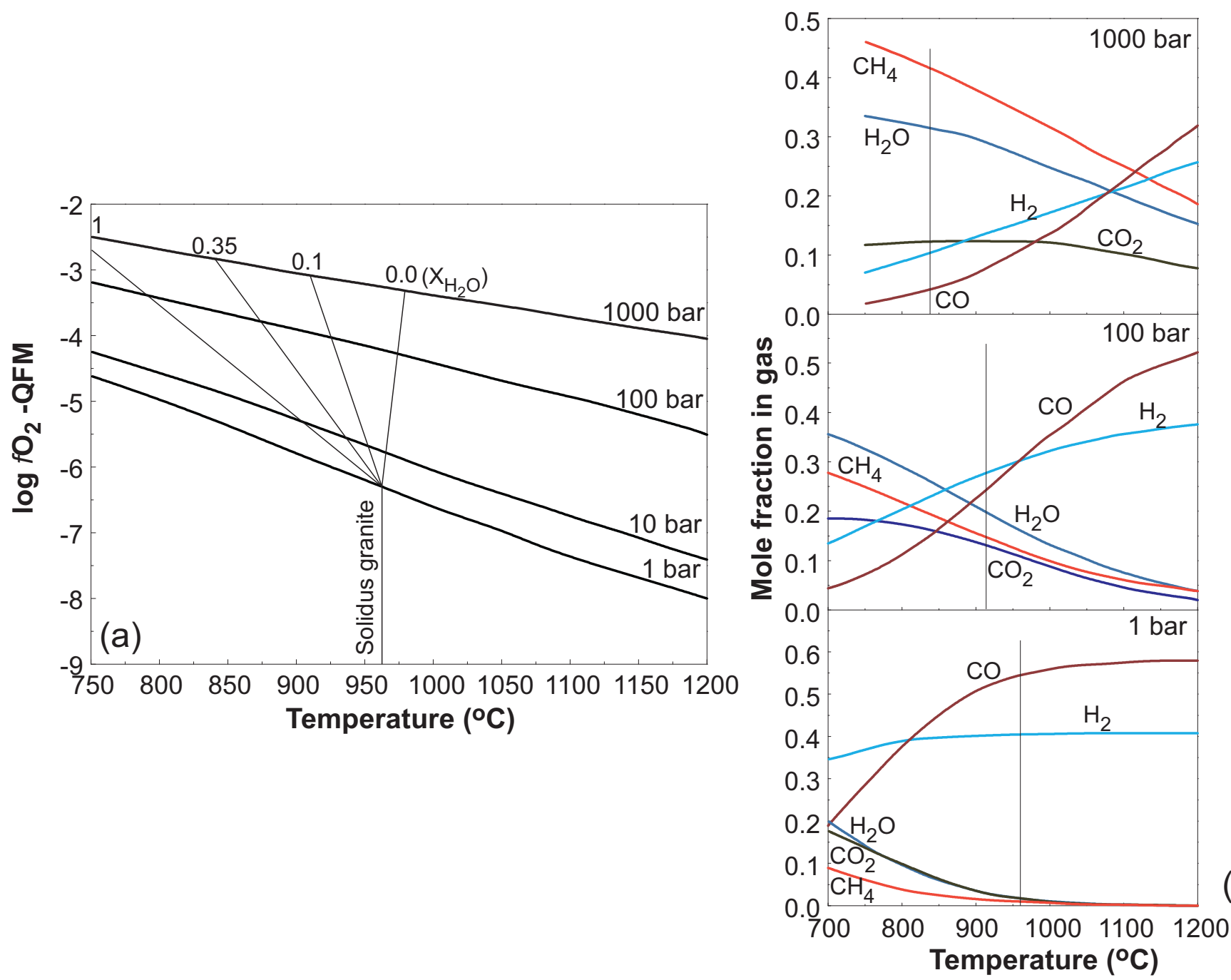

(b) 